\title{
多相黒鉛化について
}

稻垣道 $*^{*}$, 神谷寛—

1.はじめに

近年, 新しい炭素材料の開発は非常に活潑であり, そ の一環として各種の有機物質の炭化, 黒鉛化に関する研 究も盛んである。その場合, 単一の有機物質から出発し たにもか〉わらず，その高温処理物のX線回折線図形が 非常に非対称であったり, 回折角を異にし, その拡がり 巾も異なった二〜三本の回折線が重なり合ったと考えら れるような図形を示すことを経験された読者も少なくな いであろう。このような現象はすでに 1951 年 R. E.

Franklin ${ }^{1)}$ によって最初に報告されており, 彼女によ って多相黒鉛化 (multi-phase graphitization) と名付けられている。しかしながら, 近年まで工業的見 地からも，構造・物性の見地からも、コークスで代表さ れる易黒鉛化性炭素に研究・実験の重点がおかれ，その 易黒鉛化性炭素類は多相黒鉛化現象を示さないために, 多相黒鉛化に関してはほとんど注目されてこなかった。 しかし, 近年, 新しい炭素材料の開発が進められるにつ れ，多くの有機物質は難黒鉛化性炭素を生ずることが明 らかにされ，それらの多くは多相黒鉛化現象を示すこと が知られた。また，易黒鉛化性炭素も加圧下で加熱処理 した場合には多相黒鉛化に分類しうる黒鉛化現象を示す ことが知られている。したがって, 現在では多相黒鉛化 現象が多くの炭素研究者から注目され, またこれが決し て特例として片付けられる現象ではないことも認識され つつある。このように多相黒鉛化現象の研究が進んだこ とについては，自記記録式 X 線回折計が普及し，X線回 折線図形をごくルーチンに測定するようになったことが 大きな原動力となっているといえよう。また，我が国に おいては, 炭素の研究におけるX線回折法の重要性が早 くから指摘され, 日本学術振興会第 117 委員会（炭素 材料）において，標準的な測定法が決められており，多 相黒鉛化現象に関する研究, 特にそのX線回折線図形を 用いた研究が我が国において早くから盛んであることと 密接な関連がある。

本稿では, 従来の研究の中でとりあげられてきた多相 黒鉛化現象を整理し，読者の参考に供することとした。

\footnotetext{
*名古屋大学工学部：名古屋市千種区不老町 **三重大学工学部：津市上浜町
}

\section{2. 多相黒鉛化とは}

まず，どのような現象を多相黒鉛化と呼ぶかを明らか にしておく必要があろう。Fig. 1 に典型的な多相黒鉛 化を示す木炭の 002 回折線図形 ${ }^{2)}$ を示した。その加熱処 理温度にともなう変化から, この 002 回折線図形は, 少なくとも三種の図形が重なり合った結果として出来て いることが分る。 ${ }^{2,3)}$ 観測回折線図形を三つの成分図形に 分離した例 ${ }^{3)} \mathrm{Fig} .2$ に示した。この002 回折線図形 の特徵は以下のように要約できる。

A-1 ) 三種の成分図形のうち二つは面間隔 $d$ が 3.36

$\AA$ (ブラッグ角 $2 \theta$ が $26.6^{\circ}$ ) および $3.43 \AA$ ( $\left.26.0^{\circ}\right)$

の位置にあり加熱処理温度によって変動しない。そし

て, もら一種の拡がった成分図形のみが加熱処理温度

の上昇とともに面間隔 $d$ が減少し， $3.43 \AA$ に近づく。 A-2 ) 三種の成分図形の面積 (回折強度) の相対的割

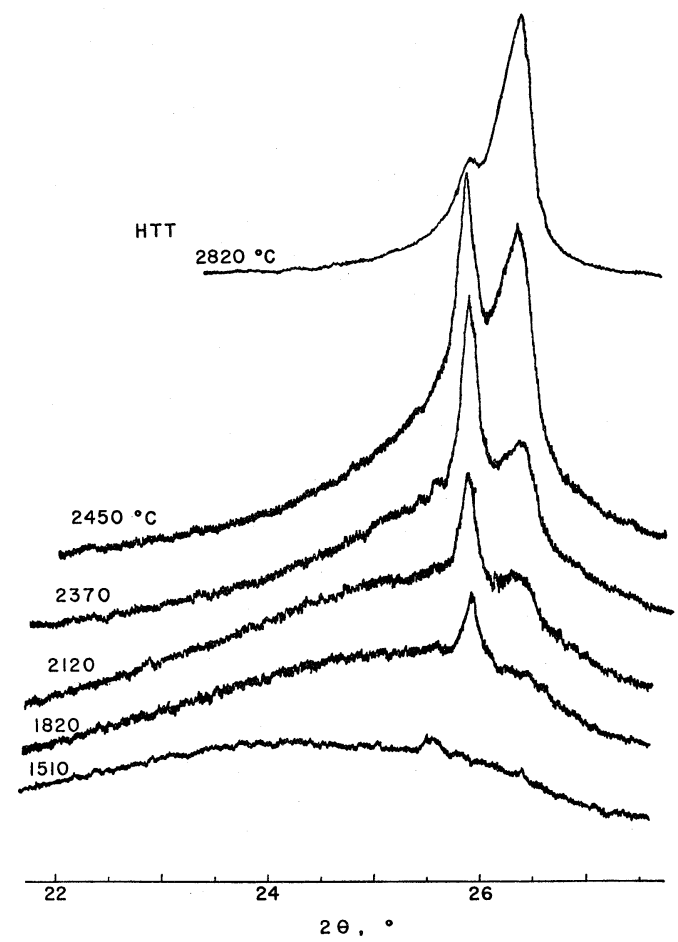

Fig. 1 木炭の002 回折線図形の加熱処理温度にとも なう変化 
今が加熱処理温度とともに変化し， $3.36 \AA$ の成分㲸 形の相対问積が增加する傾问を示す。

このような二つ以トの间折線戍形から合成された図形（ 以下これを複合洞形 composite profileと呼ぶ) が観 測されたことは，その試料中に面間隔 $d$ を異にする二種 以上の構造がX線回折では別々と区別されらるような， ある程度以上の大きさを持って共存していることを示し ている。矢沢 ${ }^{4)}$ によれば, 粉末 X線図形上で別個の回折 線として認めらるための構造の最小の抎がりは約 4000 Aであるという。

一方，たとえば易黑鉛化性炭素であるポリ塩化ビニル 炭の加熱処理にともな5004回折線図形の変化 ${ }^{5)}$ は，

Fig.3に示したようである。この黑鉛化現象は，多く の研究者によってすでによく知られているが，上記の木 炭の多相黑鉛化との対比で, その特徵を記せば，

B-1）観測回折線図形はローレンツ・偏光因子などに ついての補正を施した後は左右対称である。

$\mathrm{B}-2$ ) 加熱処理温度の上昇にともなって, 面間隔 $d$ は 徐々に減少する。

となる。測定された面間隔 $d$ の漸減は, Frankl inおよ びBaconのモデルによって説明されている。すなわち， 二種の面間隔 (黒鉛のそれ $3.354 \AA$ と乱層構造をもつ炭 素のそれ $3.44 \AA$ ) が結晶子中で全く無 秩序に配列してお おり, 加熱処理によって $3.354 \AA$ の面間隔の割合が増加 するとするものである。この黑鉛化垷象に対しては, 多 相黒鉛化と対比できるような名称はつけられていない。
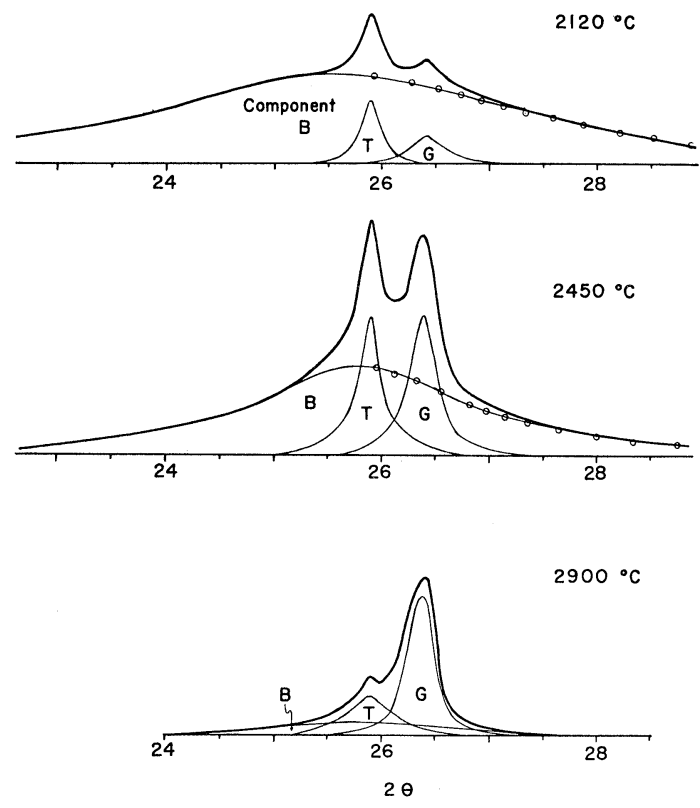

Fig. 2 複合 002回折線図形の成分図形への分離
そこで，ここではX線的に均一な構造と観測されること 加, 均一䡂鉛化 (homogeneous graphitization) と呼ぶこととする。これに対して，多相黙鉛化はX線的 に不均一な構造をもっていると観測されるので，不均一 埋鉛化 (heterogeneous graphitization) と呼ぶこ とができよう。耑黒鉛化の過程にある炭素の構造の違い をたんてきに示すために模式㘠をFig. 4 に示した。

均一拉よび不均一黙鉛化過程にある炭素のX線回折線 四形の違いは，たとえば多成分系状態圀での固溶体およ び多相共存の領域で観測される図形とそれぞれ類似して いる。ただ，炭素の場合の熱力学的平衡相は黒鉛であっ

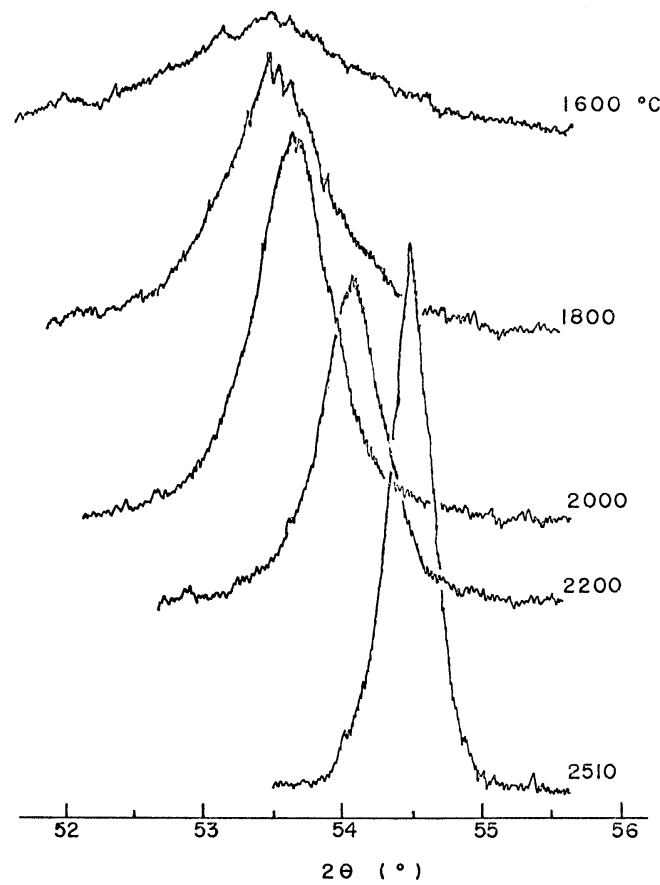

Fig.3 ポリ塩化ビニル炭の004回折線図形の加熱処 理温度にともなう変化 (均一黒鉛化過程)

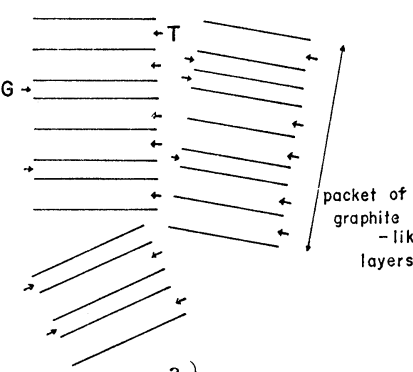

a)

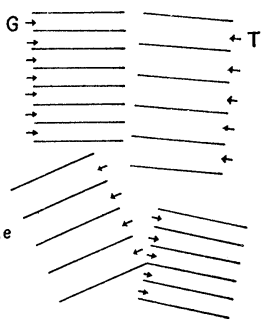

b )
Fig. 4 二種の黒鉛化過程にある炭素の構造模式図 a) 均一黒鉛化

b) 不均一黒鉛化 
て, 黒鉛化過程で観測される多相共存あるいは固溶体的 構造はいずれも非平衡相であり, 変化過程でのみ観測さ れるものであることは多成分系状態図での現象とは大き く異なっている。しかし, 熱力学的平衡相へ変化してい く過程で, 多くの相が共存したま〉で反応が進む場合も， また固溶体を生成しながら進む場合もあり，その点では 炭素の場合も全く同じである。この反応過程の違いは反 応条件によって決まることがあり，炭素の場合もまた同 様である。Fig. 5 には，常圧下で加熱処理した場合は 均一黒鉛化過程を(Fig. 3 )を示す原料炭素（ポリ塩化 ビニル $700{ }^{\circ} \mathrm{C}$ 炭化物 ) が $5 \mathrm{kbar}$ 加圧下では不均一黒鉛 化過程を経ること尚を示した。このような対比は，一部読 者の理解を助けるのに有効であろうし, また, 炭素の構 造変化が他の一般の物質からかけ離れて特異なものでは 決してないことを示すことにもなろう。

いわゆる非晶質炭素（あるいは無定形炭素）でも，そ の基本構造は炭素原子の蜂巣状の六角網面であることが 知られている。その炭素六角網面は決して完全なもので はなく，多くの欠陥をもっていると考光られるが，その 網面内での原子間隔はそれほど大巾に変動することはな い。これに対して, 網面同志の間隔, すなわち, c 軸方 向の面間隔はその網面の積み重なりの方式( 黒鉛構造的 か, 乱層構造的か)，あるいは欠陥の量によって大巾に 変動することが知られている。したがって，Fig. 1 に 示したような複合図形は $\mathrm{c}$ 軸方向の面間隔が反映される $00 \ell$ 回折線において容易に認められるものである。

一般に，相（phase）の同定はX線回折（あるいは電 子線回折）によって行なわれており，たとえば，Fig. 4 a)のよ5に二種の面間隔が無秩序に存在する場合に は，固溶体の場合と同じように一相として同定される。 したがって, “多相黒鉛化”という名称はX線回折法に よる同定によって判定されるという前提をもっていると 考えるべきである。しかし，これをより一般化して，不 均一黒鉛化と呼ぶ場合には，その同定手段を明記する必 要がある。たとえば，Fig. 4 a) に示した場合には，も し網面間隔を一つ一つ区別できるほどの分解能をもつ手 段（たとえば高分解能電子顕微鏡）を用いれば。これと て均一な構造をもっているとはいえない。

以上, 複合 $\mathrm{X}$ 線回折線図形を与える場合を多相黒鉛化 と定義してきた。しかし, 複合図形は単に観測結果とし てでてくるものにすぎず，その原因までも示していない。 したがって，観測された複合図形が見掛上のものである 場合もあるので, “多相黒鉛化”をさらに厳密に定義す る必要がある。たとえば,カーボンブラックとコークス のように黒鉛化性の異なる二種以上の原料炭素の混合物 を加熱処埋したものは，Fig.6 a)のように見掛上複合
$5 \mathrm{~kb} .20 \mathrm{~min}$

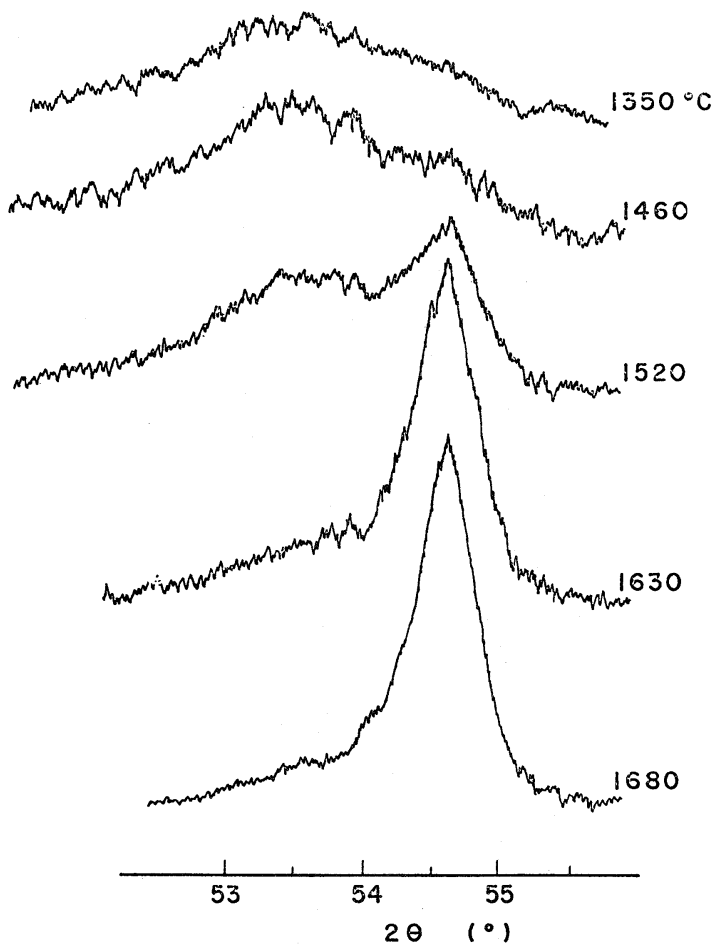

Fig. 5 ポリ塩化ビニル炭の $5 \mathrm{Rbar}$ 加圧下加熱処理試 料の 004 回折線図形（不均一黒鉛化過程）

図形を与える。 この場合の複合図形の特徵を Fig. 1 の木炭との対比で記せば以下のようになる。

C-1）成分図形の位置は必ずしも $3.36 \AA$ と $3.43 \AA$ に 決って扔らず, 加熱処理温度とともに変動し, その変 動は各原料炭素が均一黒鉛化をした場合のそれと同じ である。

C-2）成分図形の強度比は加熱処理温度によらずほぼ 一定で, 最終的に $3.36 \AA$ 成分一相になること（ある いはその傾向 )はない。

異種原料炭素間にX線回折線図形の変化として認めうる ような相互作用が無い場合に見掛上の複合図形は上記の 特徵を示す。しかし，原料炭素間に相互作用がある場合 も $2 \sim 3$ 報告されており, その場合は必ずしも上記の特 徵と合致しない。そして, その場合の複合図形はもはや 見掛上のものではなく, A と同様に本質的な多相黒鉛化 と考えるべきである。このような場合の実例を次節に記 した。

また，たとえ単一物質でも，加熱処理条件（たとえば 温度）に極端な分布がある場合には，やはり見掛上複 合図形を示すであろう。これは実験上の問題で，その原 因を取り除く以外にないが, 実際上は起こりがちなこと 

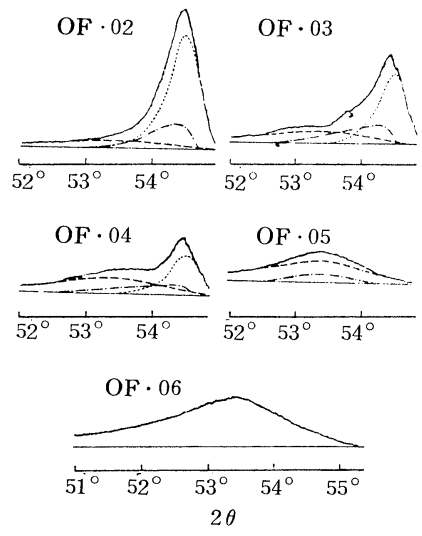

a)
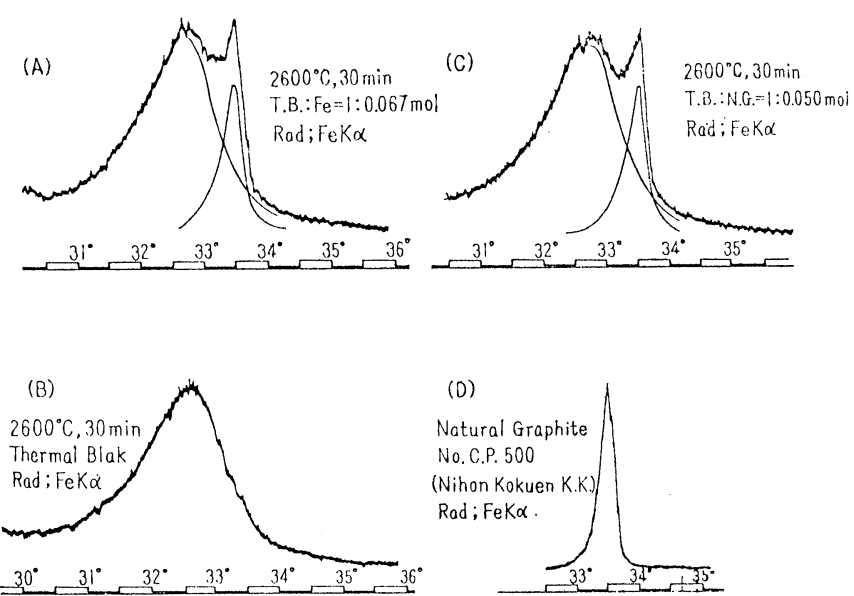

b)

Fig. 6 a) 石油コークスとファーネスブラックを結合剤ピッチを 用いて成型し, 高温加熱処理した試料の004 回折線 図形（見掛上の多相黑鉛化）

b） サーマルブラックに鉄粉を添加し $2600{ }^{\circ} \mathrm{C}$ に加熱処理 した試料の 002 回折線図形, 比較のためにサーマルブ ラック単味で加熱処理したものおよびそれと天然黒鉛 の混合物の図形も示してある。（触媒による多相黒鉛 化 )

である。この場合の複合図形の特徴はやはり, 加熱処理 によって成分図形の回折角位置が変動することである。

原料炭素に少量の金属を添加して加熱処理すると，炭 化物の生成と分解, あるいは熔融金属中への炭素の溶解 と析出, いずれかの機構によって黒鉛結晶が生成する。 それは,やはり，Fig. 6 b）に例示したように, 複合図 形を示す。この現象は黒鉛化触媒効果として多くの研究 がある。これは異物質を仲介とする黒鉛結晶の生成であ り，やはり，他の黒鉛化現象とは区別されるべきである。 この場合の複合図形の特徴を以下に要約する。

D-1）一つの成分図形は必ず $3.36 \AA$ にあるが, 他の 成分図形の位置は原料炭素の違いおよび加熱処理温度 によって異なる。

D-2） $3.36 \AA$ にある成分図形が非常に鋭く, その相 対強度は加熱処理温度, あるいは時間とともに増加す ることが多い。

最近, 大谷ら ${ }^{9)}$ はシリコンの黒鉛化触媒作用を検討した 結果, 加熱処理温度が $2200 \sim 2600{ }^{\circ} \mathrm{C}$ では $3.36 \AA$ に ある成分は全く生成せず, $3.43 \AA$ の面間隔をもつ成分 が生成すると報告した。この結果は, 同じシリコンの触 媒作用として従来報告されてきた結果と必ずしも一致し ておらず, 実験条件との関連でその現象の解明が望まれ る。この場合の回折線図形の特徵は上記の要約とは合致 しない。
Fig. 1 に木炭を例にとって示した，そして回折線図 形の特徴を A として要約した多相黒鉛化は, 上記二種( CおよびD）の黒鉛化とは異なっていると考えられる。 次節以下で記すように, その原因あるいは機構について は充分明らかになっているとは云えないが，原料炭素の 構造 (あるいは組織) が重要な因子と考えられ, その意 味ではより本質的であると云えよう。そして, この多相 黒鉛化こそが，易黑鉛化性炭素の均一黒鉛化と対比して 研究されて来たものであり，そして研究されるべきもの である。本稿では, この黒鉛化現象について以下例を記 すこととする。

\section{3. 難黒鉛化性炭素に見られる多相黒鉛化現象}

多相黒鉛化を最初に観察したのは F ranklin ${ }^{1)}$ であり, 彼女はポリ塩化ビニリデン炭および砂糖炭を加熱処理す ると, 試料の一部分だけが黒鉛化されること，およびそ の加熱処理物の 002 回折線図形が黒鉛に相当する図形 と他の一つまたは二つの図形との重なりであることを見 出し, これを二または三相黒鉛化と呼んだ。その後は, この種の現象は特殊なものと見なされたためか, そのX 線回折線図形および多相黒鉛化現象にまで触れている報 告は少ない。近年になり, フェノール樹脂炭, フルフラ 一ル樹脂炭等の黒鉛化過程をX線回折法により追跡した 結果をKobayashi ら ${ }^{10)}$ およびHonda $ら^{11)}$ が報告して 

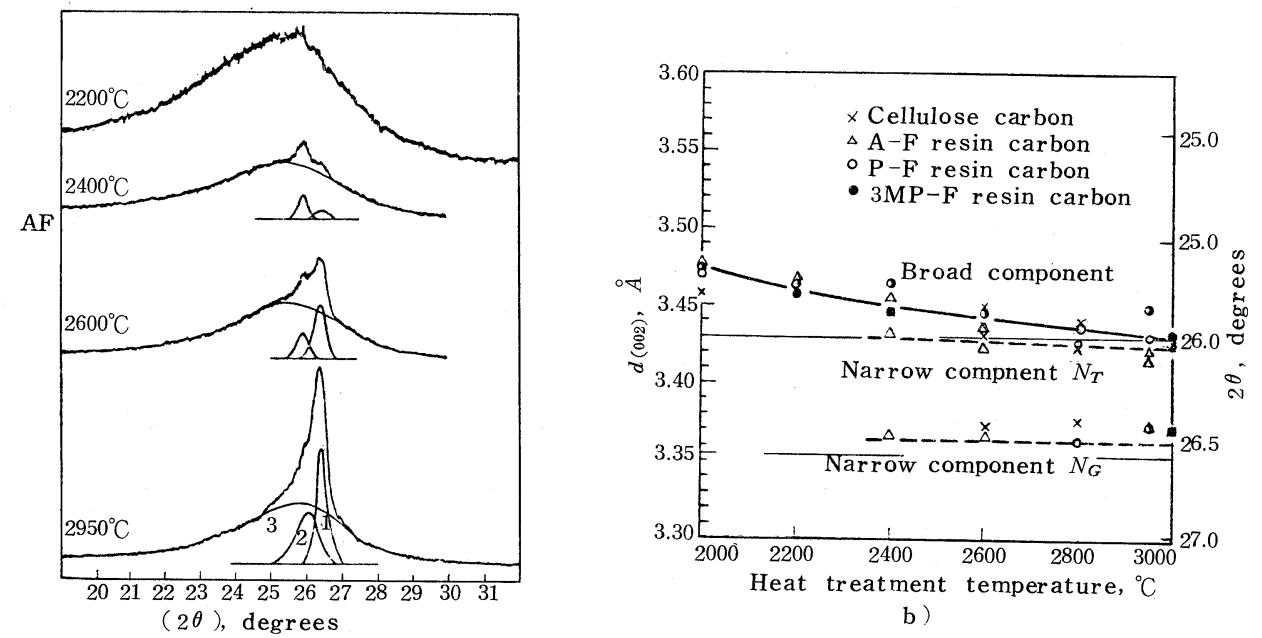

a)

Fig. 7 難黒鉛化性炭素の多相黒鉛化

a) フェノール樹脂炭の002回折線図形の分離

b）四種の炭素における各成分図形の面間隔の加熱処理温度に ともなう変化 (図中 $N_{G}, N_{T}$ および B road component がそれぞれ a) 図中の $1 ， 2$ および 3 に対応する。)

いる。彼等は, はじめて回折線図形を成分図形に分離す ることを試み，各成分図形について詳しく検討した。こ れによると, この種の炭素は多相黒鉛化を示し, その 002 回折線図形の加熱処理にともなう変化は, 前節でA として記した特徵をもち，Fig.7 a)に見られるように 非常に拡がった図形と, それよりはるかに鋭い二つの図 形から成っている。拡がった図形は, 非常に結晶子の小 さい構造あるいは非常に歪の多い構造に, 鋭い二つの図 形は面間隔 $3.36 \AA$ および $3.43 \AA$ の回折角位置にあり, それぞれ黒鉛構造および乱層構造に対応している。加熱 処理にともなう三成分の構造パラメーターはFig.7 b) に示されたように変化する。前節で記したように, 拡が った図形に対応する成分の面間隔 $d$ は加熱処理温度の上 昇とともに漸隇するのに対して, 黒鉛および乱層構造成 分の面間隔 $d$ は変化しないことが分る。また, Fig. 7

a) からも分るように, 三つの成分の量比は加熱処理温 度とともに変化している。前節で, 多相黒鉛化の例とし て記したが, 野田ら ${ }^{3)}$ は木炭を種々の温度で加熱処理し, その構造変化を追跡した結果, Fig.1に示したように, その黒鉛化過程においては三成分が出現し, 二つの鋭い 図形に対応する面間隔 $d$ は変化しないことを報告してい る。このように, 木炭は多相黒鉛化を示す代表的を原料 炭素であるが, それはセルロース, リグニン, 樹脂等の 混合物であり, 各成分を出発原料とする炭素の黒鉛化の しやすさは異なることが考えられ，木炭について観測さ れた多相黒鉛化が分類 Cに属する可能性が全くないとは

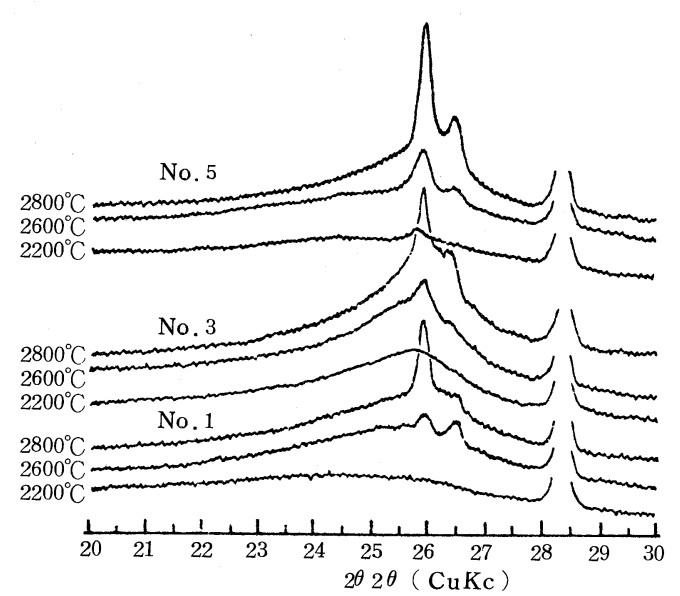

Fig.8 木炭の002 回折線図形

No. 1 末処理木炭

No.3 リグニンを除去したもの

No. 5 リグニンおよび非晶質セルローズを除去した もの

いえない。この可能性に関連して, 大谷ら ${ }^{12)}$ は順次その 構成成分を除去して加熱処理し, その黒鉛化過程を追跡 した結果, 構成成分を順次除去していった場合も黒鉛化 過程はほとんど変らないことを見出し(Fig.8)木炭が 分類 Aに属する多相黒鉛化を示すことを明らかにした。 筆者ら ${ }^{2)}$ は木炭の多相黒鉛化を定量的に取り扱ら試みの 一つとして, 複合 002 回折線図形をFig. 2 に示したよ 
らに三つの成分図形に分離し, 各成分の $\mathrm{c}$ 軸 $\overline{c_{0}}$, 量比 の加熱処理温度にともなら変化を追跡した。結果をFig 9 に示した。木炭の場合も, さきのKobayashi ら ${ }^{10)}$ お よびHonda ら $^{11)}$ の結果と同じく, 二つの鋭い罒形の $c_{0}$ はそれぞれ黒鉛および乱層構造に対応する值であり, 加熱処理温度によっては変化しない。これに対して, 拡 がった図形の $c_{0}$ だけが漸減している。また, 拡がった 図形に対応する成分の量比は, 加熱処理温度とともに減 少し, 高温では黒鉛構造を持つ成分が大部分を占めるよ うになっている。

Schiller ら $^{13)}$ は砂糖炭の高温処理物について, 3.36

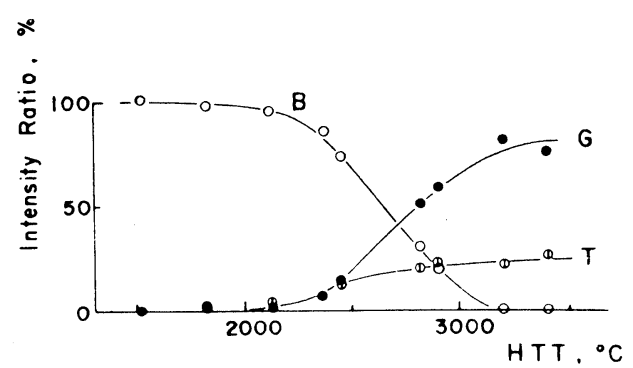

a)

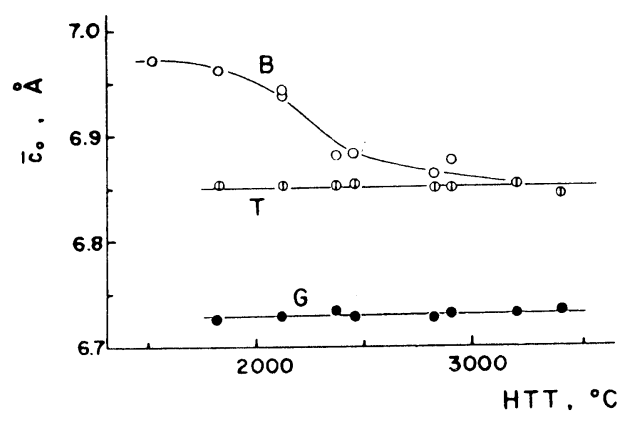

b)

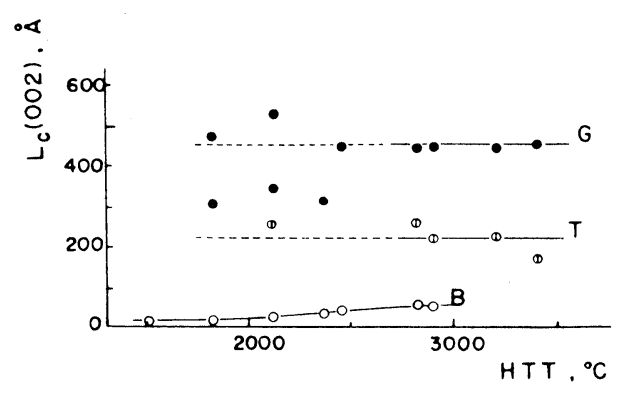

c)

Fig. 9 木炭の三つの成分図形 G, T, B (Fig. 2 参照) の強度比, $\mathrm{c}$ 軸長 $\overline{c_{0}}$, 結晶子の大きさ $L_{c}$ (002)の加熱処理温度にともなう变化
Aにある成分図形以外の図形について $\mathrm{X}$ 線的な検討を詳 細におこなった。炭素六方網面は小さく約 $75 \AA$ 市しか なく， $\mathrm{a}$ および $\mathrm{c}$ 軸方向おのおのの歪の間には, 易黒鉛 化性炭素の場合とは異なった相関性をもつことが知られ た。

Is sacs ${ }^{14)}$ は数多くの多環芳香族化合物から作った炭 素試料について, それら出発原料の構造と炭素の黒鉛化 度との関連を報告しているが, その中で, 多くのものは 難黒鉛化性炭素を与え, 多相黒鉛化現象を示すことを明 らかにした。しかし, 多相黒鉛化現象の詳細については 触れていない。

Yamada $ら^{15)}$ はポリ塩化ビニルとポリ塩化ビニリデン の混合物を出発原料とした炭素も多相黒鉛化を示すこと を報告している。ポリ塩化ビニル炭とポリ塩化ビニリデ ン炭は明らかに黒鉛化性が異なり, それら二種の混合物 の黒鉛化現象は前節での分類 Cに属すると予想されるが， 両者の混合比がある範囲（ $80 / 20 \sim 20 / 80 ）$ では, Fig.10に示すように, ほとんど同じ様相の 002 回折 線図形を与える。したがって, 原料二種の物質の混合物 であるにもかつわらず，両者の間に強い相互作用があっ て,木炭と同じ分類 Aの多相黒鉛化を示したと考えられ る。最近, Yamada ら $^{16)}$ は炭素繊維とガラスカーボンの 複合材を高温加熱処理すると, 両原料炭素 (炭素繊維と

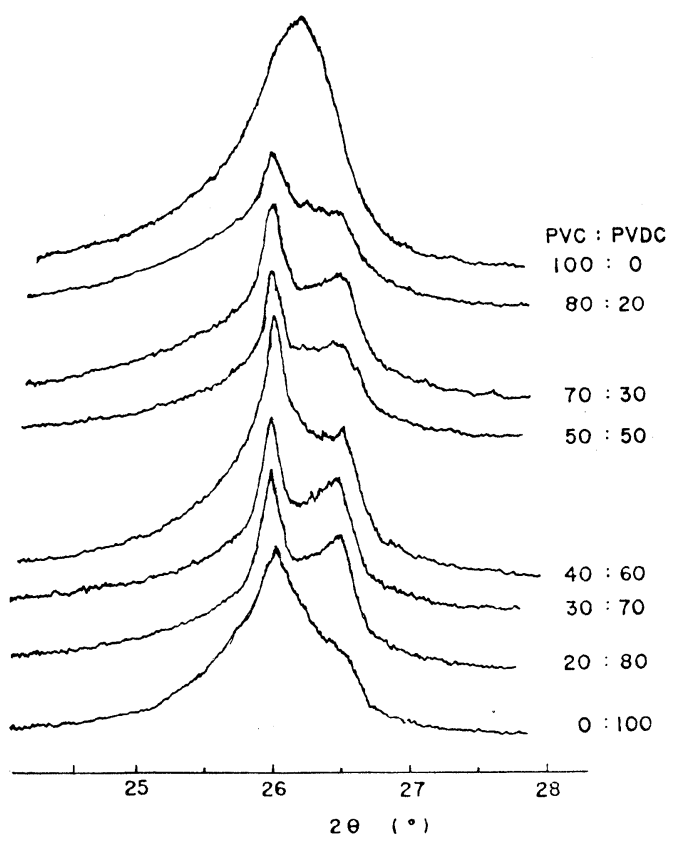

Fig. 10 ポリ塩化ビニル ( PVC ) とポリ塩化ビニリ デン（ PVDC）混合物から作った炭素の002 回折線図形 ( $2800{ }^{\circ} \mathrm{C}$ 加熱処理 ) 


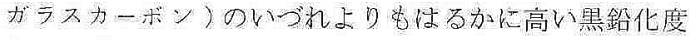

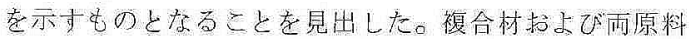
炭素の002 回折線図形を Fig. 11 に示扵。複合材の墨鉛

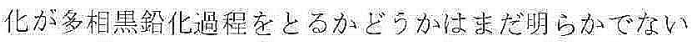
が，その谁行が両原料炭素間の非常に強い相互作用の結 果であると允よ 5 。

Frankl in ${ }^{1 \%}$ の咞究以降，多相墨鉛化見象には，素鉛

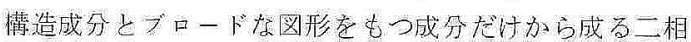

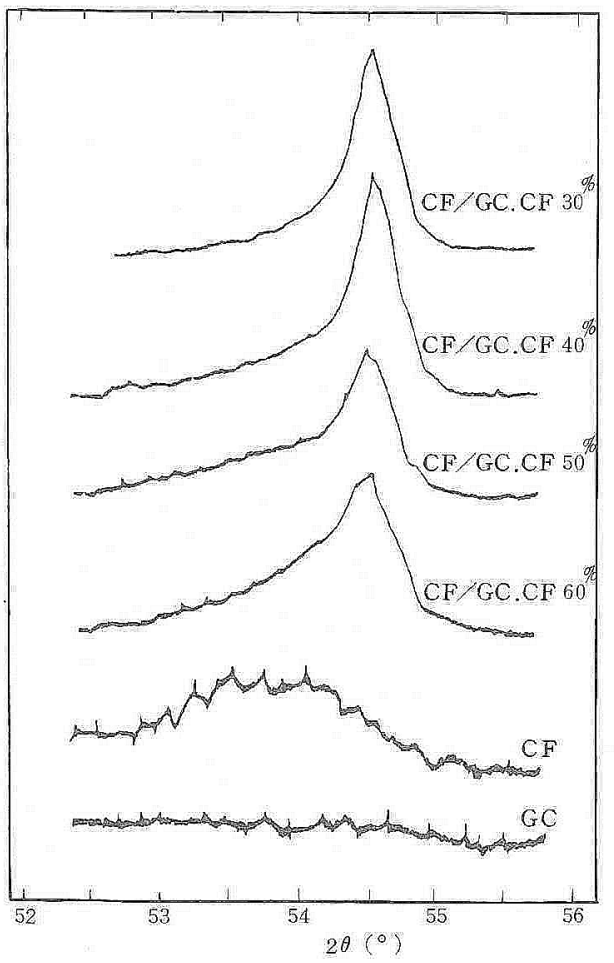

Fig.11 炭素纎維（CF)とガラスガーポソ(GC)の複 合材 0002 回折線图形 $\left(2800^{\circ} \mathrm{C}\right.$ 加熱起理 )

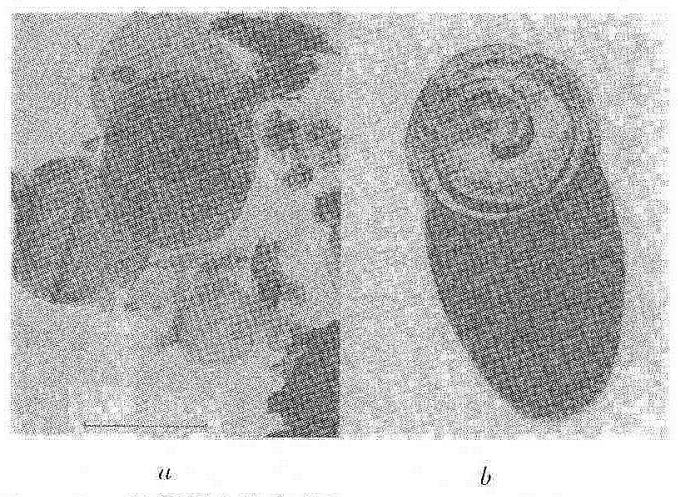

Fig. 12 難墨鉛化性炭素中に生成于る円錐状 doma in (b. 証その三炊元的モデル)
黒鉛化亡，さらに乱層構造成分 $(d=3.43 \AA)$ 加わる 三相黑鉛化の二種が存在するとされてきた。最近，

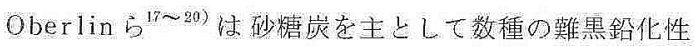
炭素の黒鉛化過程焈電子頙微鏡，電子線回折法によって

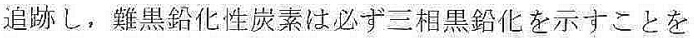
結諭した。そして，披女ら佂，二見して二相に見えるの は，乱層構造成分（佊女ら学 graphitizable phaseと 呼んでいる。が X線回折法で観測でさるほど多量に存 在しないためでるととを示した。また，各成分の棈造

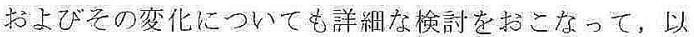

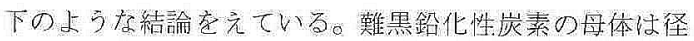

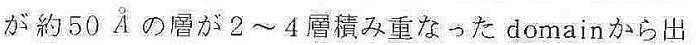
来て拈り。その domain は全く無秩序に列している。 加憼妧理すると domain は再配列 Lて网錐状（Spira-

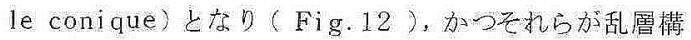
捁的に積重なった緎維状の graphitizable phase (Fig.13) を形成子る。このgraphitizable 怯次に, 途中の段階定経ずに飛躍的に黑鎦へと移行する。また, 加熱処理すると母体中に空孔索生ずるが。この空孔生成

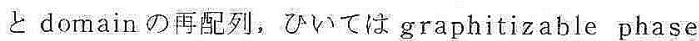
の生成，と表関連つけている。

難黒鉛化性炭素で多相黑鉛化現象加観湘さ㧈るのは， 大部分 $2000^{\circ} \mathrm{C}$ 以上であるが，ささの木岸や，フエノ一 ルメンズルデヒト樹脂炭

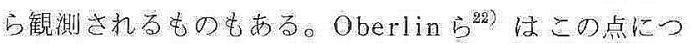

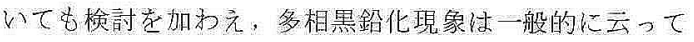
$2000^{\circ}$ C 上上で見られ，それより低い加熱処理温度で観

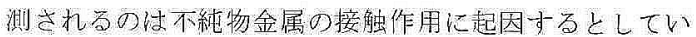
る。しかし：この点に関しては充妿の検討がなされたと

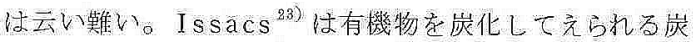
素の中心は， $1000 \sim 1300^{\circ} \mathrm{C}$ で二相黒鈖化を示すもの があることを報告して扮り，それを炭素以外の元素の除 去と関連づけている。しかし，この方与な低温での多相 黒鉛化見象につけては，曾に不純物の影響だけでなく， 父に種女検討すべ問題があるよ5に思われる。

吉田 ${ }^{24)}$ はホリ塩化ビ二ルの炭化時に, $\mathrm{CaCO}_{3}$, ある

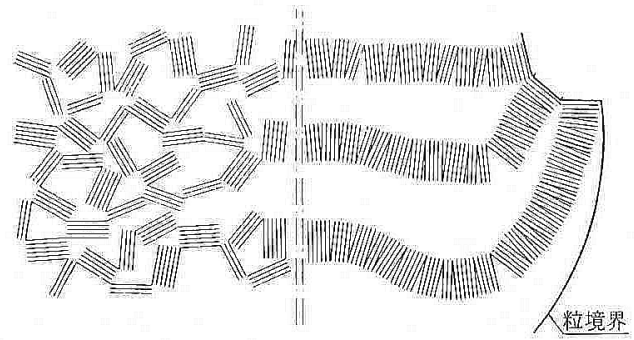

Fig. 13 㘗黑鉛化性炭素粒中での graphitizable phase 0 生成（模式図） 
いは $\mathrm{Si} \mathrm{O}_{2}$ の粉末を混入すると, 生成する炭素は分類 $\mathrm{A}$ の特徵をもつ多相黒鉛化現象を示すことを報告しており， これはポリ塩化ビニルの炭化時に添加物粉末が接触作用 をするといらよりはむしろ，粉末が存在するために流動 がおさえら机て難黒鉛化性炭素に近い炭素が生じたから であるとしている。この結果は, 出発有機物の炭化時に なんらかの外的要因を加えて, 生成する炭素の構造を変 化させれば, 通常の炭化方法では均一黒鉛化しか示さな い炭素がえられるものも，多相黒鉛化現象を示すものに 変えることができることを示している。野田ら ${ }^{25)}$ はやは りポリ塩化ビニルをオートクレーブ中で加熱・炭化する と, 多孔性の難黑鉛化性炭素がえられること,また,

Suzuki ${ }^{26)}$ はポリ塩化ビニルを塩素気流中で炭化した 場合にも難黒鉛化性炭素がえられることを報告している。 ある種のコークスに拈いては, $1600 \sim 1800{ }^{\circ} \mathrm{C}$ といっ た比較的低温で, その 002 回折線図形上に $3.36 \AA$ の面 間隔を持つ成分が少量出現し複合図形となることが知ら れている。 ${ }^{27,28)}$ Barrillonら ${ }^{27)}$ はコークス中に含まれて いる硫黄の逸脱と関連づけているが，硫黄を多く含むこ とによって出発原料コークスの組織が変化していること も考えられよ5。

4. 加圧下で加熱処理した炭素に見られる 多相黒鉊化現象

前節では，加熱処理をすべて常圧下あるいは減圧下で 行なった場合についてだけを記した。本節では加熱処理 条件に圧力の因子を加えた場合に観測される多相黒鉛化 現象について記すこととする。

ポり塩化ビニル炭は典型的な易黒鉛化性炭素であり, 常圧あるいは減压下で加熱処理する場合には均一黒鉛化 過程をとり, 単一の $00 \ell$ 回折線図形の变化として観測 される(Fig. 3 )。Noda ら ${ }^{6,29,30)}$ はポリ塩化ビニル炭 を $3 \mathrm{kbar}$ 以上の擬静水生下で加熱処理することにより, Fig. 5 に示したよ5な二相黒鉛化現象を観察した。こ の現象汁試料内の温度勾配に起因するものではなく, 311 また加圧下である程度まで二相黒鉛化を進行させた試料 を再び常圧下で高温加熱処理しても, 低角側の乱層構造 成分に対する図形のみが処理温度とともに鋭くなりなが ら高角側に移行する，すなわち，均一黒鉛化することも 知られた。 ${ }^{32)}$ これらのことから, 加圧下加熱処理によっ て見られる多相黒鉛化は, 圧力下であるために出現した ものであると結論された。

この加圧下での黒鉛化過程はポリ塩化ビニル炭を用い て, 圧力, 温度, 時間にともなら回折線図形変化を観測 することによって詳細に検討された。, $\left.{ }^{6}, 31 \sim 35\right)$ まず, 黒鉛 化の初期段階では試料の 002 回折線図形は左右対称の
ま>徐々に高角側に移行し, $26^{\circ}(d=3.43 \AA)$ に達す る。そして,その後に複合図形を示すようになり，二つ の成分の持つ面間隔は加熱処理条件によって変化せず， $3.43 \AA$ と $3.36 \AA$ であり, 両成分図形の強度比のみが変 化する。これは木炭の場合の特徵 (A) と, 非常に抎がっ た図形が存在しないことを除けば, 全く一致している。 002 回折線図形の変化の過程をFig. 14に, そして面間 隔 $d$ の変化をFig. 15に示した。一方, 加圧下で加熱処

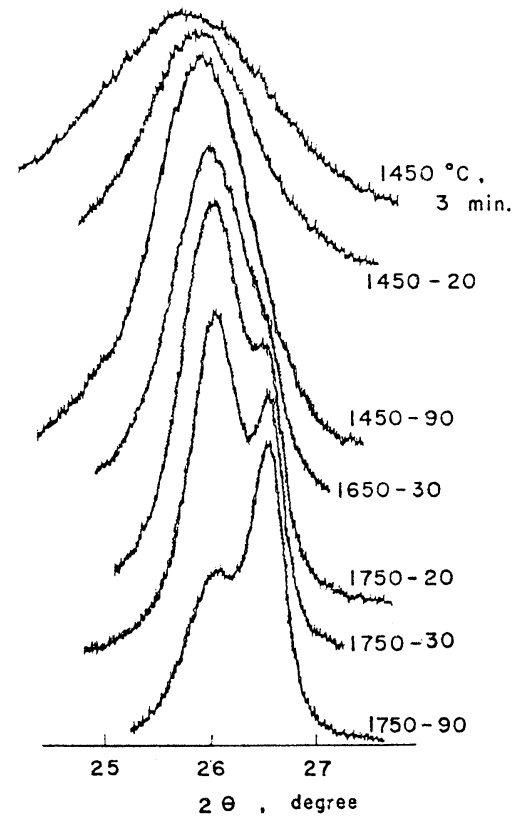

Fig.14 ポリ塩化ビニル炭の $3 \mathrm{kbar}$ 加圧下加熱処埋 試料の002 回折線図形

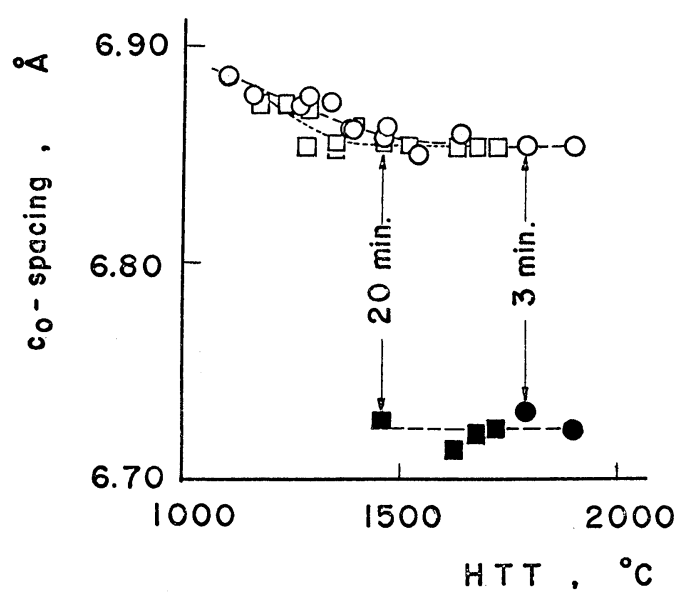

Fig.15 ポリ塩化ビニル炭の $5 \mathrm{kbar}$ 加圧下加熱処理 試料の $\mathrm{c}$ 軸長の加熱処理温度にともなう変化

○：乱層構造成分

: 乱層構造成分

○：黑鉛構造成分

$\square$ ：黑鉛構造成分 
理した試料粉末のうちのいくつかの粒は黒鉛単結晶と同 じ六方対称のスポットからなる電子線回折図形を，その 他の粒は同心円状のリングからなる図形を持つことが知 られ, 前者は黑鉛構造を持ち, X線粉末図形上での $d=$ $3.36 \AA$ の成分に対応し, 後者が乱層構造を持ち, $d=$ $3.43 \AA$ の成分に対応すると考光られた。したがって, 前者を黒鉛構造成分，後者を乱層構造成分と呼ぶことと した。黒鉛抢よび乱層構造両成分の共存する，いわゆる 二相黒鉛化の段階では, 黒鉛構造成分の量が黒鉛化度の 目安となり, これは, $00 l$. 回折線の全積分強度(すな わち全面積) に対する黒鉛構造成分の強度 (すなわち成 分図形下の面積)の比として求められる。Fig.16には 5 kbar 加圧下での黒鉛構造成分の割合の加熱処理温度にと もなう増加の様子を示した。保持時間が長時間となるに 従って，黒鉛成分量は多くなり，その出現温度も低温側 に移行している。

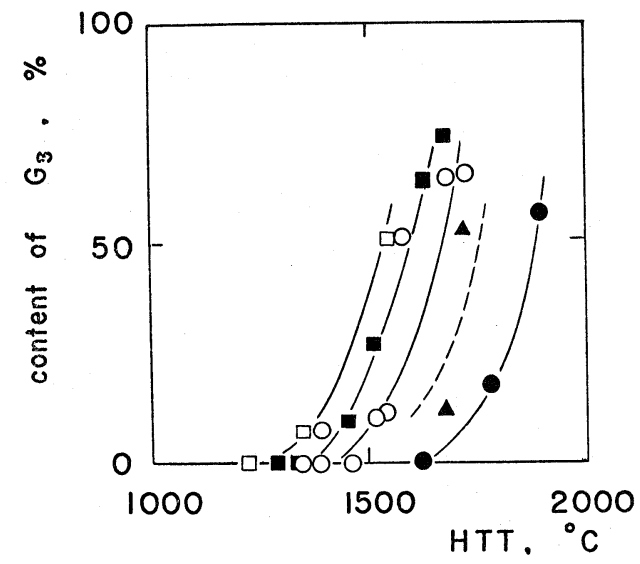

Fig.16 5 kbar 加圧下における黒鉛構造成分 Gs の加熱処理温度にともなう変化

: 保持時間 3 分, $\boldsymbol{\Delta}: 5$ 分, $\bigcirc: 10$ 分,
$\square: 20$ 分, $\square: 60$ 分

加圧下での急激な黒鉛化の進行は, 易黒鉛化性炭素に 分類されているポリ塩化ビニル炭や石油コークス ${ }^{29)}$ のみ ならず, 難黒鉛化性炭素とされているガラス状炭素 ${ }^{29}$ お

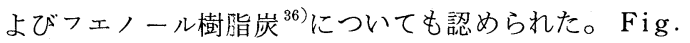
17 にフェノール樹脂炭を $5 \mathrm{kbar}$ 下で加熱処理した試 料の002 回折線図形を示した。Fig.14に示したポリ塩 化ビニル炭の場合のように明確な二相共存を示す複合図 形ではないが, 非対称な図形を示し, $1100^{\circ} \mathrm{C}$ 以上で $26.6^{\circ}\left(d=3.36 \AA\right.$ 只成分が急激に増加し, $1500{ }^{\circ} \mathrm{C}$ 以 上では非常に鋭い単一図形に変化する。Fig. 18 は $1500{ }^{\circ} \mathrm{C}$ 処理試料の粉末図形であり，101あるいは 112 などの三次元回折線がはっきりと認められ， $1500{ }^{\circ} \mathrm{C}$ 以

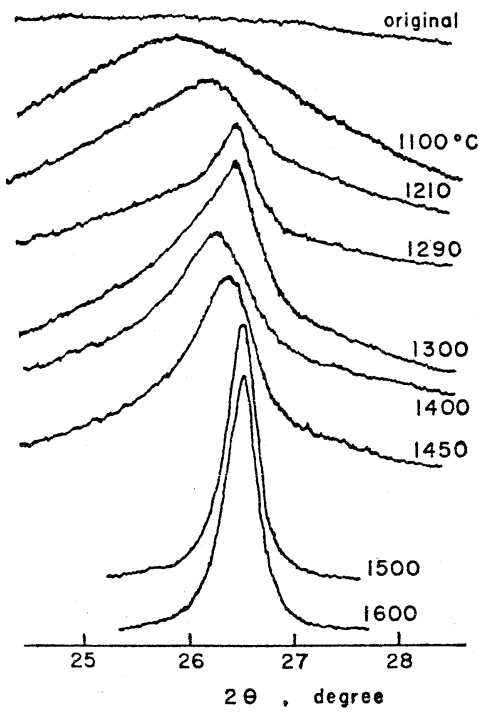

Fig. 17 フェノール樹脂炭の 5 kbar 加圧下加熱処理 試料の002 回折線図形

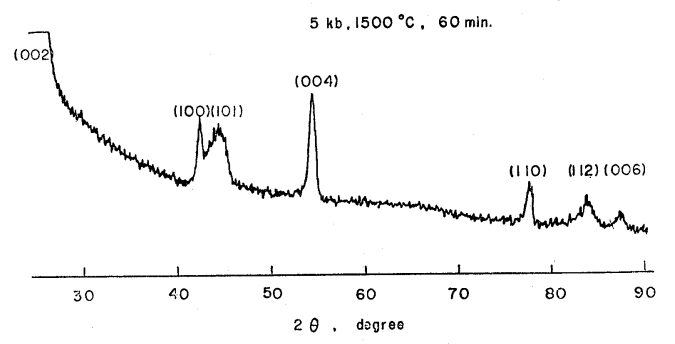

Fig. 18 フェノール樹脂炭の 5 kbar, $1500{ }^{\circ} \mathrm{C}$ 加熱 処理試料の粉末図形

上で完全に黒鉛化していることを示している。Fig.19 a)には回折線図形の分離によって求めた黒鉛構造成分 の割合を示した。黒鉛成分の増加はきわめて急激であり, ポリ塩化ビニル炭よりも急激である傾向さえ認められる。 また，この試料の電子スピン共鳴（ E S R ）スペクトル においても二本の吸収線の共存が認められた。37) そのう ちの鋭い吸収線の $\mathrm{g}$ 值は 2.003 であり, その相対強度の 測定温度依存性はキューリ一則に従い, 多くの炭化物に ついて一般的によく知られている局在スピンのそれとよ く一致している。一方, もう一本のひろがった吸収線は, その $\mathrm{g}$ 值は約 2.01 であり, その相対強度は測定温度の 上昇とともにわずかに大きくなり, 非局在スピンと関連 づけられるものであることが知られた。Fig.19 b）に は各吸収線の $\mathrm{g}$ 值を加熱処理温度に対してプロットした。 X線的に黒鉛構造成分が急増する付近で E S R 吸収スペ 


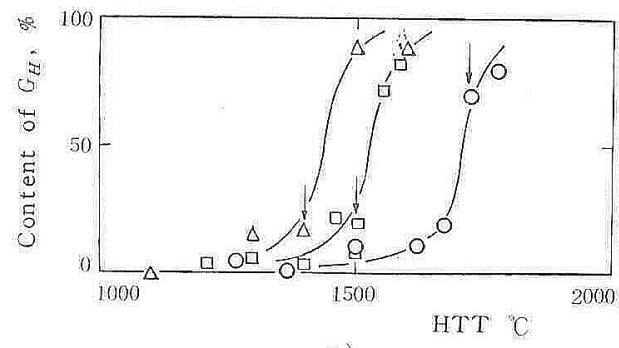

a)

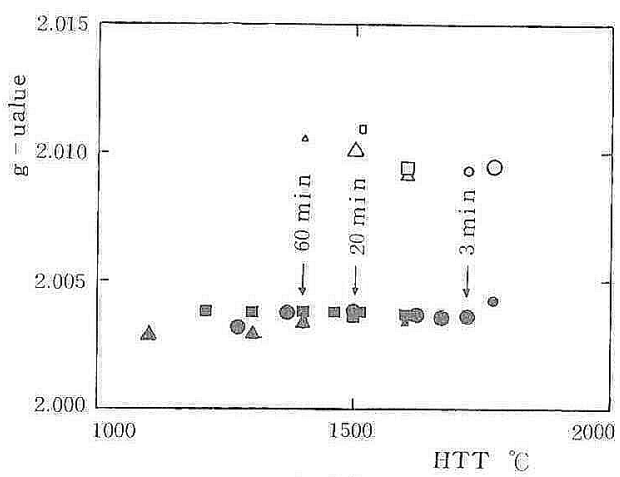

b)

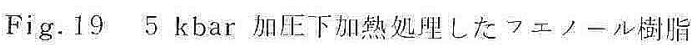
㨏に㕫けるX線回折と電子スピソ其鳴の刘忘

a) 黒跺權造成分 $\mathrm{G}_{\mathrm{H}}$ 量の变化

b) 電子スピ・其鴆吸収線の $\mathrm{g}$ 值

クトル上で非局在スピソに関連する吸収線 $(g \approx 2.01)$

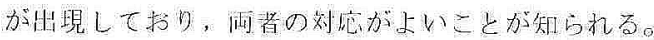

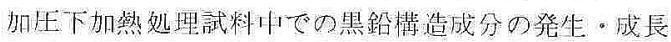

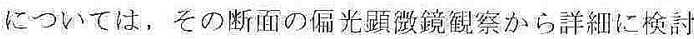

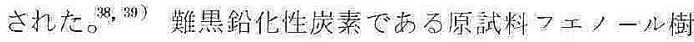
脂㞗は光学的に等方性であるのに対して，生成黑铅成分

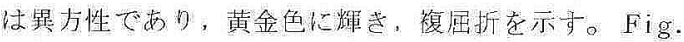
20 偏光顕徽鏡写真の一例走した。黑鉛領域が主と して原料粒の接触点，㕕い換えれば，応り集中点で発牛 していることが知られる。またこの接触点から墨塗成

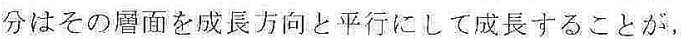

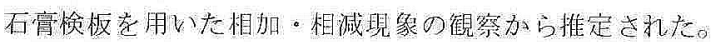

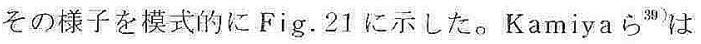

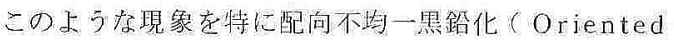
heterogeneous graphitization) と呵 S゙しと党提 案している。

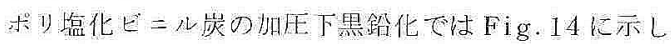

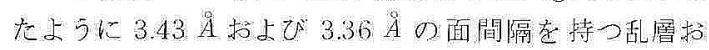

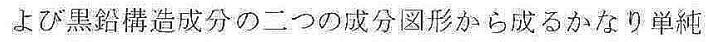
な複合図鹤老示。そして、この二つの放分図形が，前

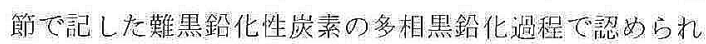

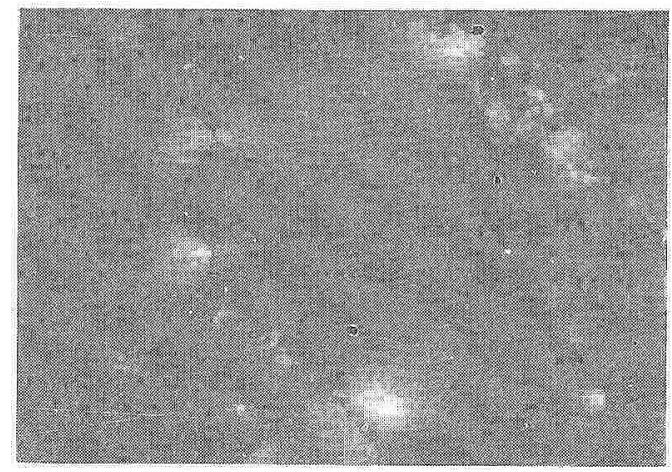

Fig. 205 kbar 加左F $1300^{\circ} \mathrm{C}$ 加䓡好理したフェ，

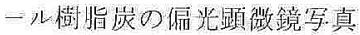

$5 \mathrm{~kb}, 1300^{\circ} \mathrm{C}$

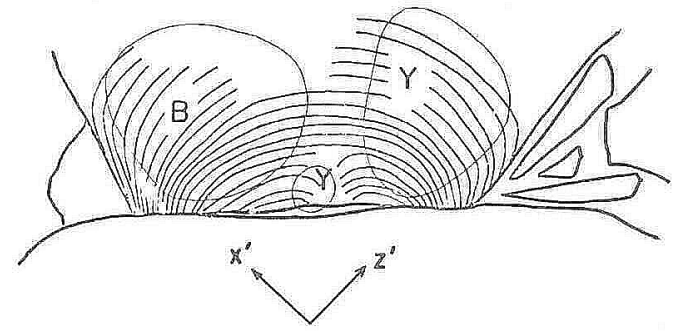

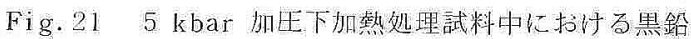
層面の限向成長（模式図）

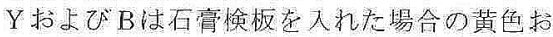

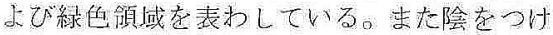
た部分が消光域圭夜わしている。

万二つの成分図眕よよく一致していることは，この二っ

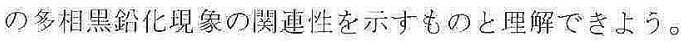
ポ塩化ビニル炭では難黑鉛化性炭素に特有新拉方った

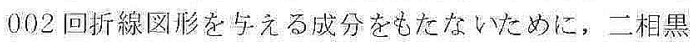
鉛化在示したと无えよ。

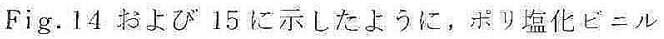

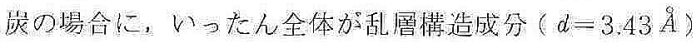
しなってから多相墨鉛化が仗じまことは，一般の黒鉛

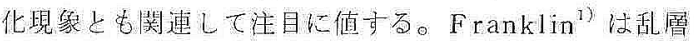

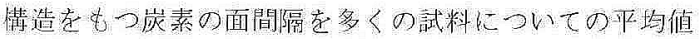

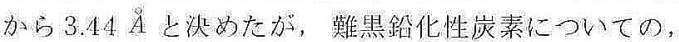

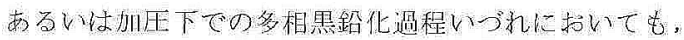

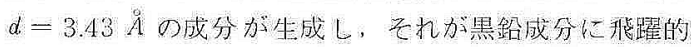

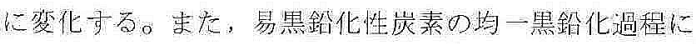

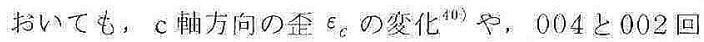

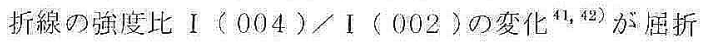

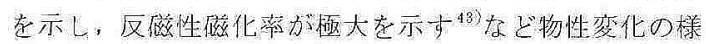
子が変ることが知られて执り，平均面間隔 $d=3.43 \AA$ 
前後で黒鉛化過程を 2 段階に分ける考え方も提案されて いる。 ${ }^{40,43,44)}$ これらの結果は黒鉛化過程に㧍ける $d=$ $3.43 \AA$ 成分の重要性を示すものと云えよう。これと関 連して, 大谷ら ${ }^{9)}$ のシリコンを添加した場合に $d=3.43$ 践分のみが生成した実験は興味が持たれよう。

Honda ら $^{45,46)}$ は石油コークス, 石炭コークスに放電 エネルギーを与えると, 前者については二相, 後者につ いては三相黒鉛化が観測されたと報告している。それに よれば, 放電エネルギーの増加とともにこれらの成分図 形は, 難黑鉛化性炭素に見られる多相黒鉛化と同じ特徴 的な変化を示した（Fig. 22）。この場合, 放電によっ て瞬間的に試料に圧力と温度とが加わ〉り，上で記した 加圧下での加熱処理と同じような状態が作り出されてい ると考えられている。しかし，極端な加熱方法であるた め, 試料内の温度分布あるいは部分的な溶融も考えられ, 分類 Cに示したよらな原因が全くないとはいえない。

\section{5. その他の多相黒鉛化現象}

前節 3 および 4 では，二または三成分図形が重なり合 った複合図形を与える多相黒鉛化について記してきた。 しかし，多くの原料炭素の中にはもっと複雑な複合図形 を与えるものも少なくない。Fig.23 a）にはその一例 としてグラッシーカーボン ${ }^{47)}$ の002 回折線図形を示し た。このような図形は，たとえば，ピッチカーボン ${ }^{48)} に$ ついても観測されている。この種の複合図形は, Fig. 2 のよらに三種の成分図形から成るとして分離すること は不可能であり，面間隔を異にする多数の成分図形の重 なり合いとして理解することができよう。しかし，そう 考える実験的根拠はまだ得られておらず，今後の課題で あろう。グラッシーカーボンの場合に, ブロックのま〉 高温加熱処理したものがFig. 23 a）のような非対称な 複合図形を与えるのに対して, 粉砕したのち高温処理し たものは Fig. 23 b) のように木炭類似の三成分から成 る複合図形を与えることが最近知られた。 この種の非対称な複合図形を解明するための実験に対す る一つのヒントとなるように思われる。

\section{6. 多相黒鉊化の機構について}

前節で，多相黒鉛化現象が起こる場合とその過程につ いて記してきた。こつでは, 多相黒鉛化の機構, 駆動力 について簡単に触れてみたい。現在のところ，黒鉛化の 機構自体についても定説はないが, 考えられている 1 2 の機構について記す。

現在最も一般的に受け入れられている黒鉛化の駆動力 はFranklin ${ }^{1)}$ および Mrozowski ${ }^{50)}$ のいら熱応力であ り，炭素の構造の反映としての異方的な熱膨張によって

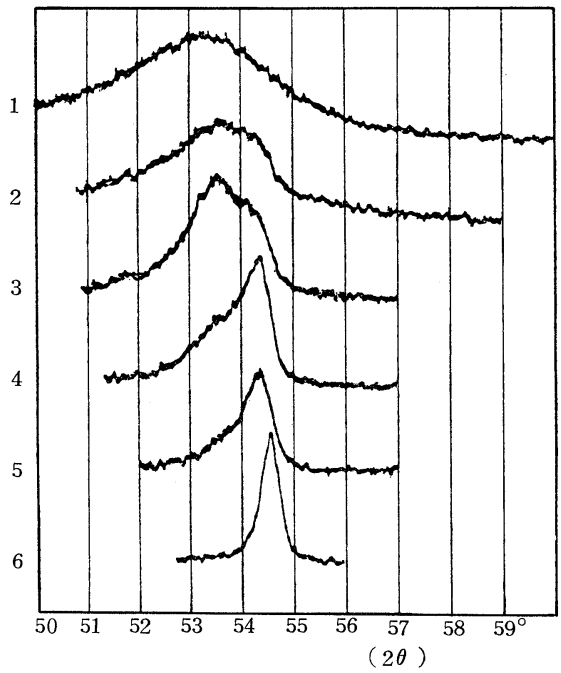

Fig.22 放電加熱処理した石油コークスの004回折線 図形

放電エネルギー（1）Ｏ J ， (2) $900 \mathrm{~J}$,

(3) $1600 \mathrm{~J}$, (4) $2500 \mathrm{~J}$, (5) $3600 \mathrm{~J}$,

(6) $4600 \mathrm{~J}$

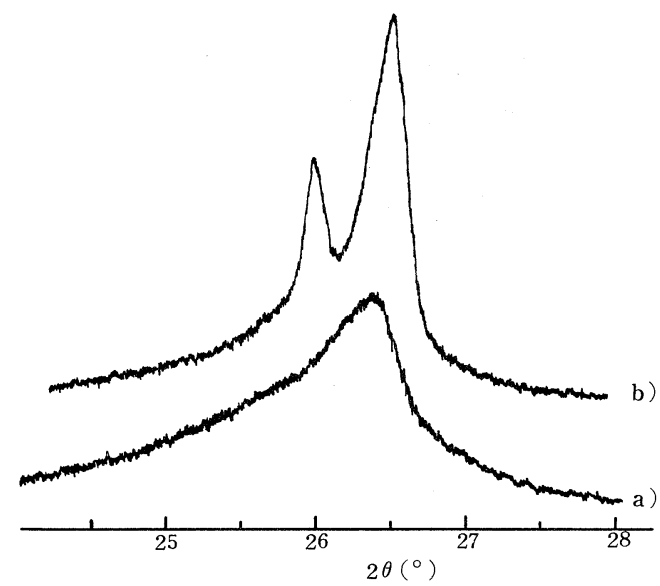

Fig. 23 グラッシーカーボン $2800^{\circ} \mathrm{C}$ 加熱処理試料の 002 回折線図形

a）ブロックのま〉加熱処理

b）炭化前に粉砕し加熱処理

生ずる歪であり，それを解消するため熱力学的平衡相で ある黒鉛構造へ移行するとされている。構造的に不純な 炭素原子という考えを導入して黒鉛化の過程を新しい観 点からとらえた Mering $5^{51)}$ の考え方も, また Inagaki ${ }^{41)}$ の wrinkling model も駆動力としての熱応力を否定 するものではない。多相黒鉛化現象が起こるのも，熱応 力の発生およびその緩和が試料内で局部的に起こるから であるとする F ranklinの考えは有力である。加圧下で 
炭素を加熱処理すると, 二相黒鉛化現象が見られ，黒鉛 化も急激に起こることは, 駆動力としての熱応力という 観点からとられることができる。加王下で, とくに応力 集中の起こる粒の接触点においては, 光学顕微鏡下でも 観測することが可能な程度の領域にわたって黒鉛構造が 発達しているのが見られ, 粒中央部の黒鉛化しない部分 と明瞭に区別できた ${ }^{38,39)}$ ( Fig. 20 参照)。これらの結 果は, 多相黑鉛化は試料内で局部的かつ集中的に応力が 発生することによって起こるといらことを裏付ける一つ の事実であろら。稲垣, 神谷 ${ }^{2)}$ は上記の実験事実に基づ き,人為的に三相黒鉛化を実現する試みを行なった。す なわち, 等方的なフェノール樹脂炭をマトリックスとし て, その中に比較的異方性の強い構造をもつポリ塩化ビ ニル炭の微粉を分散させたものを $1800{ }^{\circ} \mathrm{C}$ で加熱処理し た。その結果, Fig. 24 に示したように三つの成分図形 から成る複合 002 回折線図形をえた。等方性炭素母体中 に存在する異方性炭素の $\mathrm{c}$ 軸方向の熱膨張はおさえられ ており,52) その結果, ポリ塩化ビニル炭には大きな㴼 応力が加わ〉り, 加压下で加熱処理したときと同様二相 黒鉛化を示したと考えている。この実験で用いた試料が 三相黒鉛化現象を示すからと云って，これをそのま〉難 黒鉛化性炭素のモデルと考えるのは多分に大胆ではある が, このようなモデルを設定し, 歪の多い部分に黒鉛結 晶が生成して, それが周囲のマトリックスを消費して生 長していくと考えることも, 難黒鉛化性炭素に代表され る多相黒鉛化現象を解明しようとする一つのアプローチ であると考える。

このような考えとは異なる機構が Oberlin ら ${ }^{17,18)}$ に よって報告されている。彼女らの実験によれば, 砂糖炭 を塊状で加熱処理すると黒鉛化は進行しないが, おなじ 条件下で粉末状で加熱処理すると顕著な多相黒鉛化現象 がみられた。このことから, 黒鉛化は表面で起こると結 論している。彼女らはその機構として質量輸送を考えて 拉り, 表面に応力のかつった金属で見られるウイスカー の生長を対照して, F ranklinの内部応力説との関連か ら, 内部応力の大きい部分は欠陷も多く炭素原子の mobility も大きくなることを挙げている。

小林ら ${ }^{53)}$ は難黒鉛化性炭素の多相黒鉛化におよぼす磨 砕の影響について報告している。これによるとFig. 25 に示したように約 10 時間までの磨砕は黒鉛化を促進す るが, それ以上の磨砕は逆に黒鉛化を抑制している。磨 砕の初期段階での黒鉛化の促進は試料表面積の増大と関 連づけられうるが, 長時間の磨砕によって黒鉛化が抑制 されることについては現在のところその理由は明らかで ない。磨砕は, 試料の微粉末化の他に試料への歪エネル ギーの蓄積の効果をもつことを考え合わせると, この種
の実験も多相黑鉛化現象を解明する一つの手がかりとな ると思われる。

$$
\text { 7. おわりに }
$$

以上, 炭素の $00 \ell$ 回折線図形を測定するにあたって， 多く見られる複合四形をまずそれがよってきたる原因か ら, A) 炭素試料の構造（あるいは組織）に由来する多 相黒鉛化，Ｃ）見掛上の多相黑鉛化，Ｄ）触媒作用によ る多相黒鉛化に分類し，その中でより本質的と考えられ る A)の多相黒鉛化現象について例を挙げて, その過程 および現在考えられている機構等を概括した。

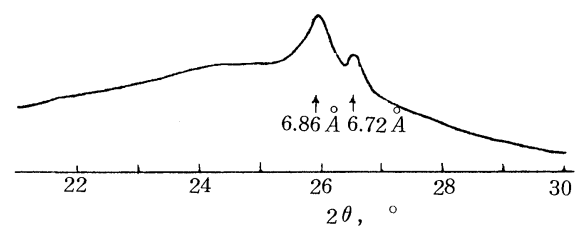

Fig.24 ポリ塩化ビニル炭の微粉を分散させたフェ， 一ル樹脂炭の 002 回折線図形 ( $1800{ }^{\circ} \mathrm{C}$ 加 熱処理 )

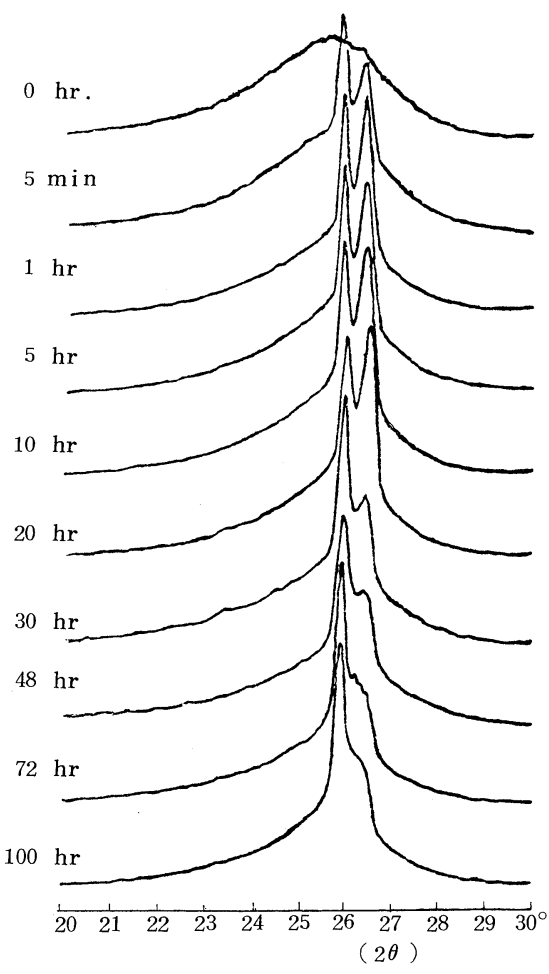

Fig. 25 フェノール樹脂炭 (32〜60メッシュ)を種々 の時間磨砕した後, $3000{ }^{\circ} \mathrm{C}$ に加熱処理した試 料の 002 回折線図形 
F is chbach ${ }^{54)}$ は，加圧下黒鉛化と難黒鉛化性炭素の多 相黒鉛化は異質の現象であるとしている。しかし，本稿 では, 両者を関連づけて議論した。この点についても, 今後種々検討していかなければならない問題と考えてい る。種々御批判, 御意見がいただきたい。

はじめに記したように, 難黒鉛化性炭素が炭素材料と して普通であり，したがって，それが示す多相黒鉛化現 象が重要な意味をもってきつつある。本稿が, 今後の多 相黒鉛化現象に関する研究の一助となれば幸である。

\section{引用 文 献}

1) R. E. Franklin, Proc. Roy. Soc. London A209, 196 (1951)

2) 稲垣, 神谷, 炭素, 1971, No. 66〕, 76

3) 野田, 稲垣, 藤沢, 工化, 64, 1370 (1961)

4) 矢沢, 炭素, 1972, [No. 70], 91

5) 稲垣, 神谷, 斉藤, 炭素, 1968,〔No. 54〕, 84

6) T. Noda, K. Kamiya and M. Inagaki, Bull. Chem. Soc. Japan, 41, 485 (1968)

7) 野田, 稲垣, 藤沢, 伊藤, 工化, 64, 1523 (1961) ; 野田, 稲垣, 杉江, 工化, 64, 2087 (1961) ; T. Noda and M. Inagaki, "Proc. 5 th Conf. on Carbon” (1962) p. 599

8）たとえば石川, 鈎, 水谷, 吉沢, 炭素, 1965 , [No. 41], 18 ; 炭素, 1965, [No. 42], 7 ; 山田, 炭素, 1965 , 〔No. 43 〕 18 ; 大谷, 大谷, 宇津木, 炭素, 1972,〔No.68〕, 10

9) 大谷, 大谷, 福田, 学振資料 $117-114-\mathrm{A}-7$ (昭 46.5.7)

10) K. Kobayashi, S. Sugawara, S. Toyoda and H. Honda, CARBON 6, 359 (1968)

11) H. Honda, K. Kobayashi and S. Sugawara, CARBON 6, 517 (1968)

12) 大谷, 大谷, 炭素, 1971,〔No.64〕, 10

13) C. Schiller, J. Méring et M. Oberlin, J. Appl. Cryst. 1, 282 (1969)

14) G. Issacs, CARBON 7,531(1969)

15) S. Yamada and M. Inagaki, CARBON 9, 691 (1971)

16) S. Yamada and K. Tamada, J. Composite Mat. ( in press ) ; S. Yamada, K. Tamada and M. Inagaki, "CARBON' 72 " at Baden-Baden にて報告

17) A. Oberlin and F. Rousseaux, C. R. Acad. Sc. Paris, 265 C, 436 (1967)

18) A. Oberlin and F. Rousseaux, J. Appl. Cryst., 1, 218 (1968)

19) A. Oberlin and F. Rousseaux, J. Appl. Cryst., 3, 105 (1970)

20) A. Oberlin, F. Rousseaux and J. P. Rouchy, Rev. Int. Hautes Tempér. et
Réfract., 7, 128 (1970)

21) E. E. Loebner, Phys. Rev. 102, 46 (1956)

22) A. Oberlin et J. P. Rouchy, C. R. Acad. Sc. Paris 268, 660 (1969)

23) G. Issacs, CARBON, 8, 1(1970)

24）吉田；私信

25）水上, 稲垣, 中, 野田, “第 4 回炭素材料に関す る夏季セミナー”テキストp. 46 (昭 41.8 )

26) H. Suzuki, S. Kimura and M. Matsui, 窯協誌, 76, 131(1968)

27) E. Barrillon, M. Denoux et A. Glay, J. Chim. Phys. ( issue special) 162 (1969) (抄訳；炭素, 1971, 〔 No.65〕, 69)

28) 稲垣, 神谷, 炭素, 1972, ( No. 70 ), 84

29) T. Noda and H. Kato, CARBON, 3, 239 (1965)

30) T. Noda, CARBON, 6, 125 (1968)

31) 稲垣, 神谷, 野田, 工化, 71,812 (1968)

32) K. Kamiya, M. Inagaki, and H. Saito, Bull. Chem. Soc. Japan, 42, 1425 (1968)

33) 稲垣, 神谷, 野田, 工化, 71, 652 (1968)

34) K. Kamiya, M. Inagaki, H. Saito and T. Noda, Bull, Chem. Soc. Japan 43,926 (1970)

35) K. Kamiya, and M. Inagaki, Bull. Chem. Soc. Japan, 44, 1712 (1971)

36) K. Kamiya, M. Inagaki, M. Mizutani and T. Noda, Bull. Chem. Soc. Japan, 41, 2169 (1968)

37) K. Kamiya, S. Yugo, M. Inagaki, H. Saito and T. Tsuzuku, Bull, Chem. Soc. Japan, 41, 7282 (1968)

38) K. Kamiya, M. Inagaki and T. Noda, CARBON , 9, 287 (1971)

39) K. Kamiya, M. Inagaki and T. Noda, High Temp. - High Press. (in press)

40) 稲垣, 炭素, 1968 (No. 53), 61; 稲垣, 村瀬, 野田, 炭素, 1968 〔No. 54 〕, 80; 稲垣, 炭素 1972 [No. 71], 124

41) M. Inagaki, Bull. Chem. Soc. Japan, 42, 2371(1969)

42) M. Inagaki, J. Appl. Cryst. 5, 295 (1972)

43) A. Pacault et H. Gasparoux, C. R. Acad. Sc. Paris, 264, 1160 (1967)

44) A. Mazza, et al., J. Chim. Phys., 61,729 (1964) ; A. Forchioni, et al., J. Chim. Phys., 61, 1289 (1964)

45) H. Honda, Y. Sanada, K. Kobayashi and T. Furuta, CARBON, 3, 429 (1966)

46) H. Honda, and K. Kobayashi, CARBON, 5, 1(1967)

47) T. Noda, M. Inagaki, and S. Yamada, J. Non-cryst. Solids, 1, 285 (1969) 
総

48）大谷, 久保田, 大谷, 小板橋, 炭素, $\mathbf{1 9 6 8}$,

[No. 52 ] 13

49) 稲垣, 山田, 玉出, 学振資料 $117-120-\mathrm{A}-10$ (昭 47.7.27)

50) S. Mrozowski, "Proc. 1 st and 2 nd Conf. on Carbon" (1956) p. 31

51) J. Mering et J. Maire, "Les Carbones" (1965) p. 129 (解説; 稲垣, 田岡, 神谷, 炭
素, 1967, [No. 48], 24)

52）神谷, 学振資料 $117-118-\mathrm{C}-5$

(昭 47.2.5)

53）小林, 白石, 真田, 学振資料 117-111-A - 1

(昭 45.10.24)

54) D. B. F ischbach, "Chemistry and Physics of Carbon Vol. 7"(1971) p.81

\section{記 真}

\section{学振第 117 委員会第 121 回会議}

昭和 47 年 9 月 29 日, 30 日の両日, 学振第 117 委員会 第 121 回会議が本郷学士会館および機械振與会館におい

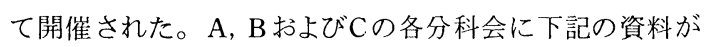
提出され，活発な討論がなされた。

\section{提出資料}

117-121-A-1 アセナフタセン，ナフタセン，ジベン ゾトリプセンの加熱生成ラジカル

公害資源研山田能生ほか

117-121-A-2 新しい炭素材料 一 その基礎はシート ポリマーの化学 一（別刷）群大工 大谷杉郎

117-121-A-3 アスファルトの変性によるバインダー ピッチの製造九工試 阿部利雄ほか

117-121-A-4 ピッチの炭化過程におけるカーボンブ ラックの挙動九工試 大井章市ほか

117-121-A-5 カーボンブラック粒子の表面極性

東大生研 萩原茂示ほか

117-121-A-6 各種炭素材料とガラスのぬれ

東工大 木村脩七ほか

117-121-B-1 酸化黒鉛より作成したカーボンフィル ムの ESR一酸化黒鉛フィルムと還元フィルム

公害資源研 豊田貞治ほか

117-171-B-2 炭素繊維/炭素複合材料の微細構造

東工大 木村脩七ほか
117-121-B-3 Siliconated Pyrolytic Graphite の 熱処理東北大金研 矢島聖使ほか

117-121-B-4ＣVD法により作製した金属元素添加 Pyrolytic Graphite(別刷)

東北大金研 平井敏雄

117-121-B-5 熱分解黒鉛ブラシの整流性能について 日本工大 武政隆一ほか

117-121-B-6 小形直流電動機負ブラシの異常摩耗に ついて 日本工大 武政隆一ほか

117-121-C-1 Pyrolytic Graphite の加圧熱処理 電通大 幸田成人ほか

117-121-C-2 ポリ塩化ビニル炭焼結体の磁性

武蔵工大 菱山幸有ほか

117-121-C-3 Carbonaceous Mosophase に関す る研究一Mesophase Spherulesの熱処理による ESRの変化 九工試 今村 健ほか

117-121-C-4 Galvanomagnetic Properties of Well-Oriented Graphite in Relation to the Structural Imperfections (別刷)

武蔵工大 菱山幸有ほか

117-121-C-5 人造黒鉛の格子定数および結晶子の大 きさ測定法 (改正案)

名大工 稲垣道夫 